\title{
UTICAJ COVID-19 INFEKCIJE NA KARDIOVASKULARNI SISTEM
}

Jedna od glavnih karakteristika COVID-19 je uticaj na srce i krvne sudove (kardiovaskularni sistem). Ne samo da su pacijenti sa prethodnim srčanim bolestima u riziku od razvoja teške forme COVID-19, već je ova bolest sada jasno prepoznata kao bolest koja može da zahvati, pored pluća, i srce i krvne sudove različitih organa $(1,2)$.

Treba se podsetiti da uticaj virusnih infekcija na srce nije nova pojava i nije karakteristična samo za COVID-19 - različite virusne infekcije, počev od virusa influence, enterovirusa, HIV, imaju sposobnost da izazovu oštećenje srčanih ćelija i krvnih sudova. Tako se, recimo, virus influence (gripa) kod 10-15\% pacijenata može ispoljiti kao akutni miokarditis (zapaljenje srčanog mišića), a rizik od nastanka infarkta miokarda je 6 puta veći tokom i neposredno po završetku virusne infekcije (1).

Korona virus se prenosi prvenstveno kapljicama, ali verovatno i putem aerosola, a u ćelije ulazi putem enzima koji konvertuje angiotenzin 2, receptora koji se nalazi ne samo u plućima, već i u srčanom mišiću i posebno krvnim sudovima (2). Ovi receptori se često nalaze u povećanom broju kod pacijenata posle infarkta miokarda, sa dijabetesom, hipertenzijom, i to je verovatno jedan od razloga zašto su pacijenti sa prethodnim srčanim bolestima i šećernom bolešću u povećanom riziku od nastanka težih formi COVID-19 $(1,2)$. Mehanizam patološkog delovanja korona virusa je višestruk i obuhvata oštećenje ćelija posredovanu citokinima, upalu endotela i mikroembolije, direktnu ćelijsku invaziju virusa, što dovodi do različitih kliničkih događaja u vidu miokarditisa, akutnih koronarnih događaja, plućne embolije, srčane slabosti, šoka i smrti $(1,2)$.

Kao što je dobro poznato, COVID-19 se tipično ispoljava kao bolest respiratornog sistema, ali značajan broj pacijenata ima od početka osećaj lupanja srca i bolova u grudima. Kardiovaskularne komplikacije se obično mogu javiti oko 2 nedelje nakon pojave simptoma COVID-19, ali se takođe mogu pojaviti vrlo rano ili čak nekoliko meseci kasnije $(1,2)$. U svakom slučaju, čini se da mikrovaskularna oštećenja počinju rano u toku bolesti, a to je ubrzo po započinjanju pandemije dovelo do preporuka za preventivnu primenu antikoagulantnih lekova. SARS-CoV-2 izaziva endotelnu disfunkciju,_bilo direktnom infekcijom endotelnih ćelija, ili indirektno infekcijom ćelija

\footnotetext{
Branko Beleslin, Univerzitetski klinički centar Srbije; Medicinski fakultet, Univerzitet u Beogradu
} 
koje izazivaju hiperinflamaciju i poremećen antivirusni odgovor. Oštećenje endotela je odgovorno za multiorgansku imunotrombozu i inflamaciju koja doprinosi razvoju teškog oblika COVID-19 (2,3,4,5). Tromboza može biti prisutna u oko 50\% kritično bolesnih pacijenata, ali takođe može biti dominantna karakteristika kod pacijenata sa samo blagim respiratornim simptomima. Trombotični događaji, od plućnih embolija, infarkta miokarda, do manifestacija na drugim organima, mogu biti jedine ili dominantne kliničke manifestacije COVID-19 (2).

U celini, mehanizmi oštećenja srca i krvnih sudova su heterogeni i isprepletani i obuhvataju direktnu virusnu invaziju ćelija, oštećenje pod uticajem hipoksije, oštećenje pod uticajem lokalne i sistemske inflamacije, endotelna disfunkcija sa trombozom i posledice hemodinamskog oštećenja desne komore.

Pokazatelji koji pacijenti su skloniji da razviju kardiovaskularne komplikacije, koji mehanizmi i klinička slika će biti dominantna, koja vrsta oštećenja na kardiovaskularnom sistemu će se razviti i kod kojeg pacijenta, ostaje uglavnom nepoznato. Međutim, kardiovaskularni komorbiditeti, kao što je hipertenzija, gojaznost, dijabetes i srčane bolesti, česte su kod pacijenata sa COVID-19 i pokazale su se kao prediktori teže kliničke slike i mortaliteta. Na Tabeli su prikazane kardiovaskularne manifestacije i komplikacije COVID-19 (1).

\begin{tabular}{|l|l|l|}
\hline \multicolumn{1}{|c|}{ Entitet } & \multicolumn{1}{|c|}{ Prezentacija/dijagnostika } & \multicolumn{1}{c|}{ Prevalenca } \\
\hline $\begin{array}{l}\text { Akutni koronarni sin- } \\
\text { drom }\end{array}$ & $\begin{array}{l}\text { Bol u grudima, hs-cTi, EKG } \\
\text { promene, eho promene }\end{array}$ & $\begin{array}{l}\text { Oko 15\% (u počet- } \\
\text { klu smanjenje pPCI) }\end{array}$ \\
\hline $\begin{array}{l}\text { Akutno oštećenje mio- } \\
\text { karda }\end{array}$ & $\begin{array}{l}\text { Srčani biomarkeri } \\
\text { Povišeni biomarkeri, normal- } \\
\text { na ili smanjena EF, edem na } \\
\text { MR, biopsija, normalna koro }\end{array}$ & $\ldots$ \\
\hline Aritmije & SVT, VT, VF, AV blok & $6-60 \%$ \\
\hline Srčana slabost & $\begin{array}{l}\text { Akutna ili dekompenzacija } \\
\text { hronične }\end{array}$ & $4-40 \%$ \\
\hline Perikardna efuzija & Eho ili CT nalaz; tamponada & $10-15 \%$ \\
\hline Plućna embolija & CT & $\begin{array}{l}10-50 \% \text { (veća kod } \\
\text { kritično obolelih) }\end{array}$ \\
\hline
\end{tabular}


Tromboza dubokih vena Ultrazvuk

4-25\% (veća kod kritično obolelih)

Moždani udar

CT ili MR

$3,3-40 \%$

\section{Hipertenzija}

Hipertenzija i dijabetes su najčešće pridružene bolesti kod pacijenata koji zahtevaju bolničko lečenje od COVID-19 (2). Štaviše, pacijenti sa hipertenzijom imaju često i teži klinički tok i ishod bolesti. S obzirom na to da stariji pacijenti često imaju i hipertenziju i dijabetes, a oba stanje su hronična pro-inflamatorna stanja i bolesti, COVID-19 kod ovih bolesnika može izazvati dodatnu i preteranu zapaljensku reakciju i tešku formu bolesti.

U početku je postojala nedoumica oko potencijalnog nepovoljnog efekta pojedinih grupa lekova - ACE inhibitora i blokatora angiotenzinskih receptora - koji se masovno koriste u lečenju hipertenzije, ali su ove kontroverze otklonjene pošto nije dokazano da nose štetan efekat na pojavu i ishod COVID-19 infekcije, tako da se mogu bezbedno koristiti $(2,6)$.

\section{Oštećenje srčanog mišića}

Sa kliničke strane, koronavirus može izazvati oštećenje ćelija srca, što se prikazuje laboratorijskim nalazom povišenog troponina (hs-cTi), koji predstavlja biomarker oštećenja ćelija srca, i koji se nalazi u 10-40\% slučajeva COVID-19 infekcije $(1,2,7)$. Ovaj veliki raspon povišenog troponina nije izraz nepreciznosti ili nepouzdanosti merenja, već podataka iz različitih istraživanja koja su obuhvatala različit broj pacijenata, težinu bolesti, vreme merenja ili metodu merenja. Pored troponina, pažnju treba obratiti na još jedan biomarker NT-proBNP, kao još jedan pokazatelj oštećenja i opterećenja srca, koji je povišen u sličnom opsegu kao i troponin $(1,2,7)$. Povećanja ovih biomarkera mogu biti posledica opterećenja rada srca u sklopu teške respiratorne infekcije, ali i direktnog oštećenja srčanog mišića, kao u slučaju ishemije miokarda ili miokarditisa.

Oštećenje srčanog mišića sa znacima miokarditisa povezano je sa težom formom bolesti i pokazatelj je lošije prognoze i direktno je povezan sa većom smrtnošću $(1,2,7)$. Aritmije se mogu javiti u $10-50 \%$ pacijenata sa COVID-19 $(2,7)$. Potencijalni mehanizmi su direktno oštećenje ćelija srca, ali i svi predisponirajući mehanizmi u koje spada hipoksija, ishemija, zapaljenja koja mogu doprineti pojavi aritmija $(2,7)$.

Praćenje oštećenja miokarda sa kliničkog "imaging" aspekta je najzastupljenije i najdelotvornije putem ehokardiografije, ali samo mali broj studija je imao sistem- 
sko ehokardiografsko praćenje kod hospitalizovanih pacijenata. Studija Giustino i saradnika (8), koja je uključila 305 hospitalizovanih pacijenata sa COVID-19 kod kojih je svima praćen hs-cTi, EKG i ehokardiogram, pokazala je da oni pacijenti koji su imali oštećenje miokarda, definisano povišenim hs-cTi (63\%), imali su značajno smanjenje ejekcione frakcije (35\% vs $10 \%)$ i poremećaje u kinetici leve komore $(24 \%$ vs $4 \%$ ). U celini, u poređenju sa pacijentima bez oštećenja miokarda (normalan hscTi), ehokardiografske promene su, pored poremećaja funkcije i kinetike leve komore, obuhvatale i dijastolnu disfunkciju (13\%), disfunkciju desne komore (26\%) i manje perikardnu efuziju (7\%). Pored toga, u grupi sa oštećenjem miokarda značajno je bilo više starijih pacijenata, osoba sa hipertenzijom, dijabetesom i hroničnom bubrežnom slabošću, koji su imali značajno veći i CRP, IL-6, D-dimer, BNP, kreatinin, LDH i AST.

U svakom slučaju, zajedno sa godinama, respiratornim distresom, prethodnom srčanom slabošću, akutnim oštećenjem bubrega, oštećenje miokarda sa ehokardiografskim poremećajima je nezavisan prediktor bolničkog mortaliteta.

Magnetna rezonanca srca predstavlja važno dijagnostičko sredstvo u proceni oštećenja srčanog mišića. Inicijalna istraživanja Puntmanna i saradnika (9) su pokazala da postoji određeni stepen oštećenja srca kod preko $70 \%$ ispitanika posle preležanog COVID-19, od kojih je oko 20\% imalo i ožiljne promene na srcu. Međutim, neophodan je veliki oprez pri razumevanju ovih nalaza s obzirom na to da se kod najvećeg broja pacijenata radi o malim ožiljnim promenama koje najverovatnije nemaju nikakve posledice na srčanu funkciju, pojavu tegoba i ne utiču na prognozu. Baš iz ovih razloga, samo odabrane pacijente za koje postoje jasni klinički pokazatelji oštećenja miokarda treba uputiti na snimanje magnetnom rezonancom radi precizne i definitivne potvrde značaja i veličine oštećenja miokarda. Snimanje magnetnom rezonancom srca u nekoliko serija pacijenata koji su bili mlađi i nisu bili hospitalizovani od COVID-19 pokazali su znake oštećenja u mnogo manjem procentu ( $<5 \%$ zapaljenske promene) (10), tako da se sada ne može sa sigurnošću govoriti o dugoročnim posledicama COVID-19 na osnovu snimanja magnetnom rezonancom, ali znaci zapaljenja i većeg oštećenja zahtevaju pažljivo praćenje i redovne kontrole.

Što se tiče infarkta miokarda i akutnog koronarnog sindroma, u početku nije primećeno posebno povećanje učestalosti, osim što je zabeležen relativni pad, a potom rast broja ovih pacijenata, što se više vezivalo za opšte efekte pandemije (manje dijagnostikovani i lečeni ne-COVID pacijenti) nego posebnim efektima virusa $(1,2,7)$. Međutim, veliki švedski registar (11) je pokazao da je učestalost infarkta miokarda ipak značajno veća u prve 2 nedelje od COVID-19 infekcije, a moždanog udara i do mesec dana, što je patofiziološki razumljivo s obzirom na dominantan prokoagulantski, mikroangiopatski, trombotički i inflamatorni patofiziološki mehanizam delovanja ovog virusa.

Treba imati u vidu i da vakcinacija (pokazano za mRNA tip vakcina) u vrlo retkim slučajevima može biti povezana sa pojavom miokarditisa (1 do 5 pacijenata na 100.000 
osoba) (12), tako da se pojava tegoba u vidu lupanja srca, bolova u grudima i zamora u periodu posle vakcinacije mora pažljivo pratiti i ispitati dopunskim analizama.

\section{Trombotični događaji}

Povreda endotela i mikrovaskularne tromboze su patofiziološke karakteristike oštećenja koronavirusom, što zajedno sa zapaljenskim sindromom i dugotrajnim ležanjem predstavljaju osnov za razvoj ozbiljnih trombotičnih komplikacija $(1,2,5)$. Što se tiče trombotičnih događaja, plućne embolije su najčešća manifestacija, koja se javlja kod skoro polovine kritično bolesnih pacijenata. Tromboza dubokih vena takođe se nalazi u oko četvrtine kritično bolesnih pacijenata. Iako se ova komplikacija češće otkriva u kasnim fazama COVID-19, neretko i posle izlaska iz bolnice, može se javiti u ranijem toku bolesti $(1,2)$. Takođe, značajan deo pacijenata sa plućnom embolijom i dubokom venskom trombozom je asimptomatski ili ima nespecifičnu kliničku sliku. U laboratorijskim analizama, povišen D-dimer, fibrinogen i drugi koagulacioni markeri koji ukazuju na tromboembolijske komplikacije uglavnom su povišeni kod pacijenata sa COVID-19, što otežava uspostavljanje praga koji bi ukazivao na dalje dopunske testove kod asimptomatskih pacijenata. Zbog toga je neophodno tokom celog toka bolesti, ali i posle izlaska iz bolnice sumnjati na pojavu ovih komplikacija i pažljivo pratiti i testirati posebno rizične pacijente; u suprotnom se tromboembolijske komplikacije mogu lako prevideti.

Ostaje otvoreno pitanje povišenih vrednosti D-dimera kod pacijenata posle otpusta iz bolnice, koji se održava kod oko $25 \%$ pacijenata pored skoro potpuno normalnih ostalih parametara koagulacije i inflamacije. Povišen D-dimer nije povezan ni sa održavanjem simptoma posle COVID-19, niti sa razvojem tromboembolijskih komplikacija (13). Nekoliko tekućih studija se bavi pitanjem potrebe za antikoagulantnom terapijom posle otpusta iz bolnice (6). Istraživanja se uglavnom odnose na primenu manjih doza novijih antikoagulantnih lekova, ali i dalje nema preporuka oko davanja antikoagulantne terapije posle preležanog COVID-19.

\section{Povratak fizičkim aktivnostima, sportu i praćenje pacijenata posle COVID-19}

Iako se preporuke za različite aspekte COVID-19 infekcije stalno koriguju i dopunjuju, što se tiče procene za ponovno bavljenje fizičkom aktivnošću i sportom preporučuje se umereno konzervativan pristup, koji obuhvata, na prvom mestu, pažljivu procenu tekućeg kliničkog stanje, težinu i trajanje COVID-19 (asimptomatska, minimalni simptomi, umereno teška, teška sa bolničkim lečenjem), EKG, laboratorijska analiza srčanog biomarkera troponina (hs-cTi) i snimanje transtorakalnom 
ehokardiografijom (14). Ovo predstavlja prvu liniju skrininga za procenu rizika za povratak fizičkoj aktivnosti i sportu u zavisnosti od vrste i obima fizičkog opterećenja. Treba imati u vidu da neki sportovi (npr. košarka) i neki sportisti (sportisti tamne puti) imaju veću predispoziciju za neželjene srčane događaje, što se mora imati u vidu pri planiranju povratku fizičkim aktivnostima i sportu.

Da stvari ne izgledaju toliko loše ukazuje i skorašnja analiza podataka Martineza i saradnika (15) na skoro 800 američkih profesionalnih sportista koji su imali asimptomatsku ili minimalno simptomatsku formu COVID-19, čije je testiranje i praćenje pokazano da je samo njih 5 (manje od 1\%) imalo dokazane znake oštećenja srca i miokarditisa (putem magnetne rezonance srca). Ovim pacijentima je privremeno zabranjeno bavljenje sportom, dok su se svi ostali sportisti vratili profesionalnom sportu i nijedan nije imao neželjen kardiovaskularni događaj.

Kod asimptomatskih ili blago simptomatskih pacijenata se predlaže odmor i prekid bavljenja sportom tokom 10-ak dana sa postepenim povratkom fizičkim aktivnostima i treningu. Međutim, kod pacijenata koji su imali umereno tešku i tešku formu bolesti sa povišenim pokazateljima zapaljenja i oštećenja srčanog mišića tokom COVID-19 treba biti posebno oprezan, povratak fizičkim aktivnostima treba da bude postupan, dok se u proceni stanja kardiovaskularnog sistema mogu, a često i treba primeniti dopunske testove i snimanja koji obuhvataju test fizičkim opterećenjem, Holter EKG i magnetnu rezonancu srca (14).

\section{Post COVID-19 sindrom ili produžen COVID-19}

Post COVID-19 sindrom predstavlja nepotpun oporavak sa održavanjem simptoma nekoliko nedelja i meseci od početka simptoma uzrokovanih COVID-19. Zamor, nedostatak vazduha, smanjena tolerancija napora se javlja u preko $50 \%$ pacijenata i to skoro $2 \mathrm{x}$ češće kod pacijenata koji su bili hospitalizovani u odnosu na one koji nisu (16). Mogu se javiti i bolovi u grudima, kašalj, anksioznost, depresija, poremećaj spavanja i koncentracije, poremećaj memorije, razni drugi simptomi. Češći je kod žena, i povezan sa jasnim smanjenjem kvaliteta života; u najvećem broju slučajeva simptomi se povuku tokom nekoliko nedelja, ali se čini opravdanim sve pacijente sa produženim COVID-19 simptomima pratiti tokom sledećih 6 meseci. Patofiziološki mehanizmi održavanja simptoma nisu razjašnjeni, međutim, jedno skorašnje prospektivno ispitivanje Sonnwebera i saradnika (17) na 145 post COVID-19 pacijenata je našlo da $41 \%$ ima i dalje simptome (najčešće nedostatak vazduha), kod kojih je najčešći razlog bila poremećena plućna funkcija sa smanjenom difuzijom gasova. Oštećenje miokarda, bilo da se radi o oštećenoj funkciji levog srca ili plućnoj hipertenziji, imalo je samo nekoliko pacijenata. CT pluća je pokazao održavanje nalaza plućne patologije u $63 \%$ pacijenata, uglavnom nalaza „mlečnog stakla” i retikula- 
cije u donjim lobusima, bez radioloških znakova plućne fibrose, ali sa tendencijom smanjenja tokom vremena (60 vs. 100 dan).

U zaključku možemo reći da postoji povezanost težih oblika COVID-19 sa postojanjem prethodnih kardiovaskularnih bolesti, dok jasno oštećenje miokarda tokom COVID-19 nosi lošiju prognozu. Povratak fizičkim aktivnostima i uobičajenom načinu života treba da bude postepen, a u slučaju prethodne srednje teške i teške kliničke slike sa hospitalizacijom zahteva redovno praćenje mogućih oštećenja plućne i srčane funkcije, laboratorijskih markera oštećenja srca i zapaljenja, funkcionalne testove i odgovarajuće imaging tehnike. Post COVID-19 simptomi se javljaju u oko $50 \%$ slučajeva, dok se objektivni pokazatelji oštećenja srčane funkcije javljaju u mnogo manjem broju osoba, dok se najčešće patološke promene posle preležanog COVID-19 ipak nalaze na plućima i odnose se na poremećaj difuzije gasova. Rehabilitacioni program i psihološka podrška su_izuzetno važni kod pacijenata sa produženim COVID-19 simptomima, uz konsultaciju specijalista za pojedine oblasti (kardiolog, pulmolog, radiolog).

\section{Literatura}

1. Pericas JM, Farrero M, Hernandez-Meneses M, et al. Coronavirus and the cardiovascular system. ESC CardioMed (3rd ed) 2020; DOI: 10.1093/med/9780198784906.003.0800

2. Guzik TJ, Mohiddin SA, Dimarco A, et al. COVID-19 and the cardiovascular system: implications for the risk assessment, diagnosis and treatment options. Eur Heart J 2020; 116: 1666-1687.

3. Bernard I, Limonta D, Mahal LK, Hpbman TC. Endothelium infection and dysregulation by SARS-CoV-2: Evidence and caveats in COVID-19. Viruses 2021; 13, 29. https://doi. org/10.3390/v13010029

4. Saddiqi HK, LibbyP, Ridker PM. COVID-19 - a vascular disease. Trend Cardiovasc Med 2021; 31. https://doi.org/10.1016/j.tcm.2020.10.005

5. P. Libby, T. Lüscher. COVID-19 is, in the end, an endothelial disease. Eur Heart J 2020; 41 (32): 3038-3044.

6. Ganatra S, Dani SS, Shaa S, et al. Management of cardiovascular disease during coronavirus disease (COVID-19) pandemic. Trend Cardiovasc Med 2020; 30: 315-325.

7. Giustino G, Pinney SP, Lala A, et al. Coronavirus and cardiovascular disease, myocardial injury and arrhythmia. J Am Coll Cardiol 2020; 76: 2011-2023.

8. Giustino G, Croft LB, Stefanini GG, et al. Characterization of myocardial injury in patients with COVID-19. J Am Coll Cardiol 2020; 76: 2043-2055.

9. Puntmann VO, Carrej L, Wieters I, et al. Outcomes of cardiovascular magnetic resonance imaging in patients recently recovered from coronavirus disease 2019 (COVID-19). JAMA Cardiol 2020; 5: 1265-1273. 
10. Rajpal S, Tong MS, Borchers J, et al. Cardiovascular magnetic resonance findings in competitive athletes recovering from COVID-19 infection (letter). JAMA Cardiol 2020; doi:10.1001/jamacardio.2020.4916

11. Katsoularis I, Fonseca-Rodriguez O, Farrington P, et al. Risk of acute myocardial infarction and ischemic stroke following COVID-19 in Sweden: a self-controlled case series and matched cohort study. Lancet 2021; 398: 599-607.

12. Barda N, Dagan N, ben-Shlomo Y, et al. Safety of the BNT162b2 mRNA COVID-19 vaccine in nationwide setting. N Engl J Med 2021; Doi: 10.1056/NEJMoa2110475

13. Townsend L, Fogarty H, dyer A, et al. Prolonged elevation of D-dimer levels in convalescent COVID-19 patients is independent of the acute phase response. $\mathrm{J}$ Thromb Haemost 2021; 19: 1064-1070.

14. Kim JH, Levine BD, Phelan D, et al. Coronavirus disease 2019 and the athlete heart . Emerging perspectives on pathology, risks, and return to play. JAMA Cardiol doi:10.1001/ jamacardio.2020.5890

15. Martinez MW, Tucker AM, Bloom J, et al. Prevalence of inflammatory heart disease in among professional athletes with prior COVID-19 infection who received systematic return-to-play cardiac screening. JAMA Cardiol 2021; doi:10.1001/jamacardio.2021.0565

16. Halpin SJ, McIvor S, Whyatt G, et al. Postdischarge symptomsand rehabilitation needs in survivors of COVID-19 infection : A cross sectional evaluation. J Med Virol 2021; 93: 1013-1022.

17. Sonnweber T, Sahanic S, Piyyini A, et al. Cardiopulmonary recovery after COVID-19: an observational prospective multicentre trial. Eur J Resp Fail 2021; 57: 2003481 [https:// doi.org/10.1183/13993003.03481-2020] 